\title{
Author Correction: ITK signalling via the Ras/IRF4 pathway regulates the development and function of Tr1 cells
}

Weishan Huang, Sabrina Solouki, Nicholas Koylass, Song-Guo Zheng \& Avery August

Correction to: Nature Communications https://doi.org/10.1038/ncomms15871, published online 21 June 2017.

The original version of this Article contained an error in the author affiliations.

Song-Guo Zheng was incorrectly associated with the 'Center for Clinical Immunology, The Third Affiliated Hospital of Sun Yat-sen University, Guangzhou, Guangdong 510630, China.'

This has not been corrected in the PDF and HTML versions of the Article.

Published online: 19 May 2020

\begin{abstract}
(c) Open Access This article is licensed under a Creative Commons Attribution 4.0 International License, which permits use, sharing, adaptation, distribution and reproduction in any medium or format, as long as you give appropriate credit to the original author(s) and the source, provide a link to the Creative Commons license, and indicate if changes were made. The images or other third party material in this article are included in the article's Creative Commons license, unless indicated otherwise in a credit line to the material. If material is not included in the article's Creative Commons license and your intended use is not permitted by statutory regulation or exceeds the permitted use, you will need to obtain permission directly from the copyright holder. To view a copy of this license, visit http://creativecommons.org/licenses/by/4.0/.
\end{abstract}

(c) The Author(s) 2020 